\title{
PRAWNE UWARUNKOWANIA BEZPIECZEŃSTWA OSÓB NIEPEŁNOSPRAWNYCH W MIEJSCU PRACY
}

\begin{abstract}
Niepełnosprawność towarzyszyła człowiekowi od początku jego bytowania na ziemi. Podstawowym problemem życiowym osób niepełnosprawnych jest znalezienie bezpiecznego miejsca w społeczeństwie, które pozwalałoby im na korzystanie z wszelakich dostępnych form aktywności zawodowej i ułożenia sobie swego prywatnego życia na równi z osobami pełnosprawnymi. Innymi słowy, jako główne wyzwanie życiowe osób z dysfunkcjami należy uznać funkcjonowanie w sposób najbardziej zbliżony do przyjętych standardów życiowych osób w pełni sprawnych i to zarówno w życiu codziennym, jak i w miejscu wykonywanej pracy zawodowej. Aby osiągnąć zamierzoną intencję niewystarczające wydają się być: wola, determinacja oraz odpowiednie predyspozycje zawodowe. Konieczne jest, aby instytucje publiczne działające na podstawie obowiązujących regulacji prawnych wraz z otoczeniem społecznym stwarzały takim osobom sprzyjające oraz bezpieczne warunki w miejscu pracy, ale też istotne są elementy rehabilitacji medycznej najczęściej związane z zapewnieniem finansowego wsparcia. Z danych zawartych w Światowym Raporcie o Niepełnosprawności wynika, że ponad miliard ludzi na całym świecie boryka się z różnymi formami niepełnosprawności, z czego od 110 do 190 milionów posiada poważne dysfunkcje uniemożliwiające im normalne funkcjonowanie w społeczeństwie, co wskazuje na ogromną skalę prezentowanej problematyki. Niniejszy artykuł prezentuje wybrane zagadnienia związane z zapewnieniem bezpieczeństwa osób niepełnosprawnych w miejscu, w którym realizują się one zawodowo omawiając najistotniejsze zagadnienia natury prawnej w tym podstawowe definicje, akty normatywne oraz orzeczenia Sądu Najwyższego w przedmiotowym zakresie.
\end{abstract}

Słowa kluczowe: bezpieczeństwo, niepełnosprawność, praca.

\section{WPROWADZENIE}

Problematyka bezpieczeństwa osób niepełnosprawnych realizujących się w różnych aspektach aktywności życiowej, w tym zawodowej, aktualnie jest mocno zdynamizowana. Taki stan rzeczy wynika z przemian, jakie mają miejsce we wszystkich sferach funkcjonowania życia publicznego.

Zmiany te obierają dwa oblicza. Po pierwsze, dają szansę na swobodne kreowanie swojej osoby oraz otoczenia, z drugiej zaś strony mogą powodować zagubienie człowieka

\footnotetext{
${ }^{1}$ Dr Oktawia Jurgilewicz, Katedra Prawa i Administracji, Wydział Zarządzania, Politechnika Rzeszowska im. Ignacego Łukasiewicza, ul. Akademicka 2, 35-084 Rzeszów; e-mail: niemieco@prz. edu.pl.

Oktawia Jurgilewicz, PhD, Department of Law and Administration, Faculty of Management, Rzeszów University of Technology, Akademicka 2, 35-084 Rzeszów; e-mail: niemieco@prz. edu.pl.
} 
w gąszczu nowych informacji, które mogą powodować stan lęku, co w rezultacie może doprowadzić do poczucia zagubienia, zagrożenia, a nawet i stanów depresyjnych stwarzając tym samym niebezpieczeństwo dla zdrowia człowieka. Jak zatem należy postrzegać pojęcie bezpieczeństwa przez osoby niepełnosprawne oraz w jaki sposób uściślając prezentowany wątek odnieść daną problematykę do miejsca wykonywania przez te osoby pracy zawodowej?

W pierwszej kolejności należy odpowiedzieć sobie na pytanie: czym jest bezpieczeństwo? W literaturze przedmiotu można spotkać wiele definicji i podziałów omawianego pojęcia. Bezpieczeństwo niewątpliwie jest naczelną, wielorodzajową wartością, która obejmuje wiele różnorodnych atrybutów, które przypisywane są wielorakim kryteriom, tj.: społecznym, gospodarczym, ekonomicznym, ekologicznym czy też moralnym.

Trudno jest w sposób jednoznaczny określić termin „bezpieczeństwo”. Chcąc wyjaśnić prezentowany termin można w pierwszej kolejności przywołać jego znaczenie w tłumaczeniu z języka angielskiego, co w rezultacie wskazuje, iż bezpieczeństwo oznacza brak zagrożeń (ang. danger) oraz poczucie pewności (ang. safety) ${ }^{2}$. Z kolei w Stowniku terminów z zakresu bezpieczeństwa narodowego bezpieczeństwo określono jako „stan, który daje poczucie pewności, i gwarancje jego zachowania oraz szansę na doskonalenie. Jest to jedna z podstawowych potrzeb człowieka lub też sytuacja odznaczająca się brakiem ryzyka utraty czegoś, co człowiek szczególnie ceni; na przykład: pracy, zdrowia, uczuć, szacunku, dóbr materialnych"3. W takim ujęciu bezpieczeństwo jawi się jako wartość dla każdego podmiotu (ludzi, państw czy grup społecznych). Pozwala to stwierdzić, że bezpieczeństwo dotyczy nie tylko pojedynczej jednostki ludzkiej, ale też większych społeczności oraz „obejmuje zabezpieczenie potrzeb: istnienia, pewności, przetrwania, stabilności, tożsamości, nie-

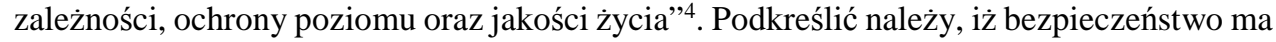
charakter uniwersalny, ponieważ dotyczy każdego społeczeństwa, każdej kultury, ale także i każdej pojedynczej osoby w tym szczególne znaczenie ma dla osób z niepełnosprawnością, które to poza tradycyjnymi aspektami związanymi z danym pojęciem muszą jeszcze brać pod uwagę swoją wyjątkową sytuację życiową.

Bezpieczeństwo zatem jest wartością, która może obierać różne oblicza w zależności od sytuacji podmiotu, którego dotyczy. Problem zapewnienia bezpieczeństwa można rozpatrywać z perspektywy osób niepełnosprawnych, co stanowi przedmiot analizy w niniejszym artykule.

\section{POJĘCIE I RODZAJE NIEPEŁNOSPRAWNOŚCI}

Niepełnosprawność to zjawisko będące funkcją negatywnych reakcji społecznych (wyizolowania, stygmatyzacji, dyskryminacji) na inność osoby z dysfunkcją, zmuszającą ją wskutek stereotypów istniejących w danym środowisku do przyjęcia takich definicji własnej roli i statusu społecznego, które powodują jej wykluczenie (lub też poważne

\footnotetext{
2 J.W. Gould, W.L. Kolb (red.), A Dictionary of the Social Sciences, London 1964, s. 629.

${ }^{3}$ J. Kaczmarek, W. Łepkowski, B. Zdrodowski (red.), Stownik terminów z zakresu bezpieczeństwa narodowego, Warszawa 2008, s. 14.

${ }^{4}$ E. Nowak, M. Nowak, Zarys teorii bezpieczeństwa narodowego, Warszawa 2011, s. 13.
} 
ograniczenie) z uczestnictwa w zwykłej aktywności społecznej i ekonomicznej członków danej społeczności ${ }^{5}$.

Niepełnosprawność jest zjawiskiem dynamicznym i rozwojowym. Świadczą o tym m.in.: rozwój relacji osób zdrowych do osób z niepełnosprawnością, zwiększający się obszar wiedzy dotyczący tego środowiska (głównie propagowany przez media społecznościowe), jak też rozwój technologiczny stwarzający nowe metody rehabilitacji. Zgodnie ze stanowiskiem Międzynarodowego Forum UNESCO stosunek społeczności, która jest w pełni zdrowa do tej, która wykazuje pewne dysfunkcje można uporządkować i podzielić na pięć następujących po sobie etapów, tj.:

1. etap filantropijny, w którym osobę niepełnosprawną traktowano jako jednostkę upośledzoną, niezdolną do podjęcia pracy, niepotrafiącą decydować o sobie, wymagającą nieustannej opieki i pomocy ze strony ludzi zdrowych;

2. etap tzw. towarzystw dobroczynności, w którym człowiek z ograniczoną sprawnością przymuszony był do funkcjonowania w różnorodnych ośrodkach czy instytucjach pomocowych;

3. etap podstawowych praw, w którym uznano, iż osoby z niepełnosprawnością także są beneficjentami określonych praw, np. prawa do bezpiecznej i higienicznej pracy;

4. etap przyznawania osobom niepełnosprawnym praw zbliżonych do praw przysługujących jednostkom zdrowym, w którym zaakcentowano konieczność edukowania osób niepełnosprawnych, przygotowywania do podjęcia pracy zarobkowej oraz usamodzielniania;

5. etap powszechnych praw gwarantowanych dla osób niepełnosprawnych, który związany jest z zaakceptowaniem przez ogół społeczeństwa faktu, iż w jego obrębie żyją jednostki niepełnosprawne, które wymagają określonych warunków do optymalnego funkcjonowania ${ }^{6}$.

Niepełnosprawność stanowi jedno z tych interdyscyplinarnych pojęć, które funkcjonuje w obszarze różnych nauk: pedagogiki, socjologii, psychologii, czy też medycyny. Jego jednoznaczne zdefiniowanie jest niezwykle trudne $\mathrm{z}$ uwagi na niejednorodne rodzaje dysfunkcji we współczesnym życiu społecznym. Pojęcie niepełnosprawności pojmowane jest jako: defekt, inwalidztwo, kalectwo, odchylenie od normy, upośledzenie czy też uszkodzenie. Są to jednak niekiedy pojęcia marginalizujące czy też stygmatyzujące dany stan faktyczny.

Media społecznościowe również dysponują swoimi terminami usiłując zachęcić swoich odbiorców do uwagi. Najczęściej posługują się takimi terminami jak: osoby sprawne inaczej, specjalnej troski czy ze specjalnymi potrzebami. Prezentowane nazewnictwo poddawane jest nieustannej krytyce z uwagi na jej niejednoznaczność, ogólnikowość, akcentowanie odmienności i kojarzenie niepełnosprawności ze stanem rozgoryczenia, zatroskania czy też trudności ${ }^{7}$.

W literaturze przedmiotu funkcjonuje wiele definicji prezentowanego zjawiska. Można przyjąć w sposób ogólny, na potrzeby danego artykułu, iż za niepełnosprawność uważać

${ }^{5}$ B. Gąciarz (red.), Niepetnosprawni studenci w społeczności akademickiej. Źródta sukcesów i porażek w integracji społecznej i aktywności zawodowej, Warszawa 2010, s. 11.

${ }^{6}$ I. Książkiewicz, M. Lejzerowicz, Osoba z niepetnosprawnościa a instytucje pomocowe, Wrocław 2012, s. 27.

7 S. Sadowska, W stronę innego spojrzenia na szkote jako miejsca terapii ucznia z niepetnosprawnościq intelektualna, „Człowiek - Niepełnosprawność - Społeczeństwo”, Kwartalnik Akademii Pedagogiki Specjalnej im. Marii Grzegorzewskiej, nr 1, Warszawa 2005, s. 17. 
należy funkcjonalne ograniczenie utrudniające jednostce sprawne poruszanie się, słyszenie, widzenie, mówienie czy też myślenie. Znaczący wkład w usystematyzowanie różnorakich terminologii pojęcia niepełnosprawności wniosła Światowa Organizacja Zdrowia (WHO), która to w roku 1980 zatwierdziła Międzynarodową Klasyfikację Uszkodzeń Niepełnosprawności i Upośledzeń. W myśl jej zapisów uszkodzenie traktowane jest w kategoriach biomedycznych i oznacza ,wszelką utratę lub wadę struktury anatomicznej narządów i (lub) czynności fizycznych czy psychicznych".

Niepełnosprawność ujmowana jest jako „wszelkie ograniczenia lub brak, wynikający z uszkodzenia zdolności wykonywania czynności na poziomie uważanym za normalny dla człowieka. Upośledzenie rozumiane jest jako niekorzystna (gorsza) sytuacja osoby, będąca wynikiem uszkodzenia lub niepełnosprawności, polegającą na ograniczeniu lub uniemożliwieniu wypełniania ról, które uważane są za normalne pod względem płci, wieku, czynników kulturowych i społecznych"8.

W tym miejscu zwrócić należy uwagę na różne oblicza niepełnosprawności istotne dla celów pozarentowych, które w świetle polskiego prawa ujęte zostały w tzw. stopnie niepełnosprawności, których status usankcjonowany został w ustawie z dnia 27 sierpnia 1997r. o rehabilitacji zawodowej i społecznej oraz zatrudnianiu osób niepełnosprawnych ${ }^{9}$ orzekane przez zespoły do spraw orzekania o stopniu niepełnosprawności, które to mogą wydać decyzję administracyjną stwierdzającą o:

1. znacznym stopniu niepełnosprawności, do których zalicza się osobę z naruszoną sprawnością organizmu, niezdolną do pracy albo zdolną do pracy jedynie w warunkach pracy chronionej i wymagającą, w celu pełnienia ról społecznych, stałej lub długotrwałej opieki i pomocy innych osób w związku z niezdolnością do samodzielnej egzystencji;

2. umiarkowanym stopniu niepełnosprawności, do których zalicza się osobę z naruszoną sprawnością organizmu, niezdolną do pracy albo zdolną do pracy jedynie w warunkach pracy chronionej lub wymagającą czasowej albo częściowej pomocy innych osób w celu pełnienia ról społecznych.

3. lekkim stopniu niepełnosprawności, do których zalicza się osobę o naruszonej sprawności organizmu, powodującej w sposób istotny obniżenie zdolności do wykonywania pracy, w porównaniu do zdolności, jaką wykazuje osoba o podobnych kwalifikacjach zawodowych z pełną sprawnością psychiczną i fizyczną, lub mająca ograniczenia w pełnieniu ról społecznych dające się kompensować przy pomocy wyposażenia w przedmioty ortopedyczne, środki pomocnicze lub środki techniczne;

4. niezdolności do samodzielnej egzystencji, która oznacza naruszenie sprawności organizmu w stopniu uniemożliwiającym zaspokajanie bez pomocy innych osób podstawowych potrzeb życiowych, za które uważa się przede wszystkim samoobsługę, poruszanie się i komunikację ${ }^{10}$.

Dla celów rentowych orzecznictwo zostało w Polsce zakwalifikowane do kompetencji lekarzy orzeczników oraz komisji lekarskich wydających decyzje w takich instytucjach jak: Zakład Ubezpieczeń Społecznych (ZUS), Kasa Rolniczego Ubezpieczenia Społecznego (KRUS), Ministerstwo Obrony Narodowej (MON) oraz Ministerstwo Spraw Wewnętrznych i Administracji (MSWiA). Kwestie związane z podstawowymi definicjami unormo-

\footnotetext{
8 C. Barnes, G. Mercer, Niepetnosprawność, Warszawa 2008, s. 21-23.

9 Tekst jedn. Dz.U. z 2018 r. poz. 511 ze zm. (dalej jako: urzon).

${ }^{10}$ Art. 4 urzon.
} 
wane zostały w ustawie z dnia 17 grudnia 1998 r. o emeryturach i rentach z Funduszu Ubezpieczeń Społecznych ${ }^{11}$.

Natomiast niezdolną do pracy w rozumieniu ww. ustawy jest osoba, która całkowicie lub częściowo utraciła zdolność do pracy zarobkowej z powodu naruszenia sprawności organizmu i nie rokuje odzyskania zdolności do pracy po przekwalifikowaniu. Całkowicie niezdolną do pracy jest zaś osoba, która utraciła zdolność do wykonywania jakiejkolwiek pracy. Za częściowo niezdolną do pracy ustawa uznaje osobę, która w znacznym stopniu utraciła zdolność do pracy zgodnej z poziomem posiadanych kwalifikacji ${ }^{12}$.

Niewątpliwie zatem uznać należy, iż problematyka niepełnosprawności dotyczy całego społeczeństwa bez względu na bariery środowiskowe, społeczne, czy też i ekonomiczne. Wobec powyższego to społeczeństwo zobligowane jest do eliminowania, zmniejszania lub też kompensowania barier, jakie stwarza dana kategoria niepełnosprawności. W odpowiedzi na takie zachowanie społeczność dysfunkcyjna będzie się odwdzięczała samodzielnością w funkcjonowaniu i to nie tylko w życiu rodzinnym, ale również i w charakterze pracownika.

\section{PODSTAWY PRAWNE ZATRUDNIANIA OSÓB NIEPELNOSPRAWNYCH}

Podstawowym aktem pranym regulującym proces zatrudniania osób niepełnosprawnych jest Konwencja nr 159 Międzynarodowej Organizacji Pracy dotycząca rehabilitacji zawodowej i zatrudnienia osób niepełnosprawnych, która przyjęta została w Genewie w dniu 20 czerwca 1983 r. $^{13} \mathrm{~W}$ prezentowanym akcie normatywnym zawarto definicję osoby niepełnosprawnej, która w świetle omawianego dokumentu oznacza osobę, której możliwości uzyskania i utrzymania odpowiedniego zatrudnienia oraz awansu zawodowego są znacznie ograniczone w wyniku ubytku zdolności fizycznych lub umysłowych, właściwie orzeczonego ${ }^{14}$. Tak więc pojęcie niepełnosprawności określone jest poprzez tzw. ubytek zdrowotny, który winien być stwierdzony właściwym aktem administracyjnym. W Polsce są to, jak wspomniano, orzeczenia wydawane przez instytucje państwowe, które nadając odpowiedni status danej osobie, nadają jej też możliwości socjalne w postaci prawa do różnego rodzaju świadczeń. Taka polityka zmierzać ma do zapewnienia, aby właściwe środki rehabilitacji zawodowej były dostępne dla wszystkich grup osób niepełnosprawnych oraz do popierania możliwości zatrudnienia osób niepełnosprawnych na otwartym rynku pracy.

Omawiana polityka winna być oparta na zasadzie równości szans pracowników niepełnosprawnych i innych pracowników. Winna być więc przestrzegana zasada równości szans i traktowania niepełnosprawnych pracowników płci męskiej i żeńskiej. Specjalne, pozytywne środki, zmierzające do zagwarantowania rzeczywistej równości szans i traktowania pracowników niepełnosprawnych i innych pracowników, nie powinny być traktowane jako środki dyskryminujące. Wskazuje się, iż realizacja tej polityki, włączając w to środki, jakie powinny być podejmowane w celu popierania współpracy i koordynacji działań instytucji publicznych i prywatnych, zajmujących się rehabilitacją zawodową, będzie konsultowana z reprezentatywnymi organizacjami pracodawców i pracowników. Będzie ona też konsul-

11 Tekst jedn. Dz.U. z 2018 r. poz. 1270 ze zm. (dalej jako: uFUS).

12 Art. 12 uFUS.

13 Dz.U. z 2005 r., nr 43, poz. 412 (dalej jako: Konwencja MOP).

14 Art. 1 ust. 1 Konwencji MOP. 
towana z reprezentatywnymi organizacjami osób niepełnosprawnych i organizacjami działającymi na ich rzecz ${ }^{15}$.

W dalszej części Konwencji MOP określono działania, jakie powinny być realizowane na szczeblu krajowym na rzecz rozwoju rehabilitacji zawodowej i służb zatrudnienia osób niepełnosprawnych ze wskazanie na to, iż:

- każdy Członek winien podejmować, w drodze ustawodawstwa krajowego lub w każdy inny sposób zgodny z warunkami i praktyką krajową, wszelkie kroki, jakie mogą być niezbędne do wprowadzenia w życie ww. zasad;

- właściwe władze zobowiązane są do tego, aby podejmować środki w celu utworzenia i oceny działania służb poradnictwa zawodowego, szkolenia zawodowego, pośrednictwa pracy, zatrudnienia i innych podobnych służb ${ }^{16}$, umożliwiających osobom niepełnosprawnym uzyskanie i utrzymanie zatrudnienia oraz awans zawodowy; istniejące służby dostępne dla ogółu pracowników będą wykorzystywane, zawsze, gdzie jest to możliwe i celowe, po niezbędnym ich przystosowaniu;

- podejmowane winne być kroki w celu popierania tworzenia i rozwijania służb rehabilitacji zawodowej i zatrudnienia osób niepełnosprawnych na obszarach wiejskich i w odosobnionych skupiskach ludności;

- każdy Członek winien zmierzać do zapewnienia przeszkolenia i dostępności doradców oraz innego wykwalifikowanego personelu do spraw rehabilitacji zawodowej, odpowiedzialnych za poradnictwo zawodowe, szkolenie zawodowe, pośrednictwo pracy i zatrudnienie osób niepełnosprawnych ${ }^{17}$.

Kolejnym aktem prawnym, w którym określone zostały zasady związane z zatrudnianiem osób niepełnosprawnych jest dyrektywa nr 2000/78/WE ustanawiająca ogólne warunki ramowe równego traktowania w zakresie zatrudnienia i pracy ${ }^{18}$, której głównym celem jest wyznaczenie ogólnych ram dla walki z dyskryminacją ze względu na religię lub przekonania, niepełnosprawność, wiek lub orientację seksualną w odniesieniu do zatrudnienia oraz pracy, w celu realizacji w państwach członkowskich zasady równego traktowania $^{19}$. Dyrektywa ramowa w odniesieniu do osób niepełnosprawnych formułuje pojęcie dyskryminacji jako sytuację, w której pracodawca lub każda osoba, do której odnosi się niniejsza dyrektywa na mocy przepisów krajowych nie podejmuje właściwych środków zgodnie z zasadami w niej określonymi, w celu zlikwidowania niedogodności spowodowanych danym przepisem, kryterium lub też praktyką ${ }^{20}$. Prezentowany akt normatywny w art. 5 nadaje też swoiste uprawnienia osobom niepełnosprawnym, gdzie celem zagwarantowania im przestrzegania zasady równego traktowania przewiduje się wprowadzenie racjonalnych usprawnień. Oznacza to, że pracodawca winien podejmować właściwe środki, z uwzględnieniem potrzeb konkretnej sytuacji (życiowej danej osoby), aby umożliwić osobie niepełnosprawnej dostęp do pracy, wykonywanie jej lub rozwój zawodowy bądź kształcenie, o ile środki te nie nakładają na pracodawcę nieproporcjonalnie wysokich obciążeń. Obcią-

\footnotetext{
15 Art. 2-5 Konwencji MOP.

${ }^{16}$ W Polce wytyczne te realizowane są m.in. przez Państwowy Fundusz Rehabilitacji Osób Niepełnosprawnych, którego główną misją jest ułatwianie osobom niepełnosprawnym pełnego uczestnictwa w życiu zawodowym i społecznym.

17 Art. 6-9 Konwencji MOP.

18 Dz.U. UE. L. z 2003 r., nr 303, s. 16 (dalej jako: dyrektywa ramowa).

19 Art. 1 dyrektywy ramowej.

${ }^{20}$ Art. 2 ust. 2 dyrektywy ramowej.
} 
żenia te nie są nieproporcjonalne, jeżeli są w wystarczającym stopniu rekompensowane ze środków istniejących w ramach polityki prowadzonej przez dane państwo członkowskie na rzecz osób niepełnosprawnych ${ }^{21}$. Przywołany artykuł ma niezwykle istotne znaczenie dla niepełnosprawnego pracownika gdyż nakładają na pracodawcę obowiązek stworzenia optymalnych warunków do pracy swojemu niepełnosprawnemu pracownikowi. Nie chodzi tu tylko o zapewnienie ergonomicznego stanowiska pracy, ale również o aspekt psychologiczny związany z wyrównywaniem różnic pomiędzy pracownikiem w pełni sprawnym a tym, który dysponuje orzeczeniem o pewnej dysfunkcji.

Należy również podkreślić, że niezwykle istotne w dzisiejszych czasach są elementy związane ze wsparciem psychologicznym (coraz częściej pracodawcy decydują się, aby zatrudniać psychologa na potrzeby swego personelu), ale również z motywowaniem swoich pracowników poprzez różnego rodzaju szkolenia, kursy czy nawet zagraniczne staże. Takie motywowanie pracownika nadaje mu poczucie wsparcia psychicznego, poczucie bezpieczeństwa, by finalnie motywować go do dalszego działania. Niepełnosprawność fizyczna często bowiem pobudza do innego postrzegania zwyczajnych problemów, jakie niesie ze sobą wykonywanie danej pracy. Najczęściej ma to miejsce w sytuacji, w której osoba staje się nie w pełni dyspozycyjna w wyniku wypadku, który to niekiedy bezpowrotnie odmienił jej dalsze życie. Dlatego też prezentowany artykuł staje się swoistego rodzaju dyspozycją skierowaną do pracodawcy, czego niewątpliwą pozytywną konsekwencją będzie zadowolenie i zapewne większa efektywność pracy swojego niepełnosprawnego pracownika.

Kontynuując wątek odnoszący się do prezentacji podstawowych norm prawnych w przedmiocie zatrudniania osób niepełnosprawnych kolejnym punktem do rozważań staje się art. 69 Konstytucji Rzeczypospolitej Polskiej22, zgodnie z którym osobom niepełnosprawnym władze publiczne winne są udzielać pomocy w zabezpieczaniu egzystencji, przysposobieniu do pracy oraz komunikacji społecznej. Adresatem obowiązków wynikających z prezentowanego artykułu Konstytucji RP są „władze publiczne”, więc wszelkie organy i instytucje pozostające w strukturze władzy państwowej szczebla centralnego bądź samorządu terytorialnego, a także realizujące zlecone zadania z zakresu administracji. Wspomniany zapis nie tworzy bezpośrednio żadnych obowiązków po stronie podmiotów niepublicznych, jest jednak oczywiste, że ustawodawca zwykły jest uprawniony do sformułowania takich obowiązków, w szczególności pod adresem pracodawców, inwestorów itp. ${ }^{23}$

Ponadto istotne jest wskazanie, na czym konkretnie ma polegać wspomniane udzielanie pomocy. Można w tym aspekcie dokonać podziału na trzy dziedziny życia społecznego, tj.:

- zabezpieczenia egzystencji zobowiązując władze publiczne do stworzenia odpowiednich mechanizmów zabezpieczenia społecznego dla osób niepełnosprawnych;

- przysposobienia do pracy (co nakazuje tworzenie szczególnych programów szkoleniowych i przystosowawczych, a także wprowadzanie systemu zachęt i ułatwień dla zatrudniania osób niepełnosprawnych);

- komunikacji społecznej (co nakazuje tworzenie odpowiedniej infrastruktury, umożliwiającej niepełnosprawnym przemieszczanie się i nawiązywanie kontaktów z innymi ludźmi) ${ }^{24}$.

${ }^{21}$ Art. 5 dyrektywy ramowej.

22 Dz.U. z 1997 r., nr 78, poz. 483 ze zm. (dalej jako: Konstytucja RP).

${ }^{23}$ L. Garlicki, M. Zubik (red.), Konstytucja Rzeczypospolitej Polskiej. Komentarz, t. II, wyd. II, Warszawa 2016 (lex online 20.09.2018 r.).

${ }^{24}$ Ibidem. 
Z kolei wart odnotowania jest także fakt, iż ustawodawca w przywołanym artykule nie zawiera konstytucyjnego obowiązku udzielania pomocy do innych sfer aktywności życiowej osób niepełnosprawnych, niemniej jednak interpretacja danego przepisu winna skłaniać się ku szerszemu spojrzeniu na daną problematykę i odnosić się również do pomocy w sferze dostępu do edukacji czy też pełnego udziału w życiu publicznym.

Natomiast podstawowym aktem prawnym, w którym ustawodawca zawarł liczne wytyczne dla pracodawców, jakie muszą spełnić podczas procesu zatrudniania pracowników niepełnosprawnych, jest wspomniana ustawa z 27 sierpnia 1997 r. o rehabilitacji zawodowej i społecznej oraz zatrudnianiu osób niepełnosprawnych. Zakres przedmiotowy ustawy skupia się wokół osób, których niepełnosprawność została potwierdzona orzeczeniem o zakwalifikowaniu przez organy orzekające do jednego z trzech stopni niepełnosprawności o całkowitej lub częściowej niezdolności do pracy na podstawie odrębnych przepisów lub o niepełnosprawności, wydanym przed ukończeniem 16. roku życia ${ }^{25}$.

Prezentowana ustawa reguluje ponadto takie zagadnienia jak: sposób wliczania osób niepełnosprawnych do stanu zatrudnienia, rodzaje i opis poszczególnych stopni niepełnosprawności, procedurę orzekania o niepełnosprawności, Elektroniczny Krajowy System Monitoringu Orzekania o Niepełnosprawności, rehabilitację osób niepełnosprawnych, uprawnienia osób niepełnosprawnych, szczególne obowiązki i uprawnienia pracodawców w związku z zatrudnianiem osób niepełnosprawnych, zakłady pracy chronionej i zakłady aktywności zawodowej, zadania i organizację służb działających na rzecz osób niepełnosprawnych, szkolenie osób niepełnosprawnych, Krajową Radę Konsultacyjną ds. Osób Niepełnosprawnych, Państwowy Fundusz Rehabilitacji Osób Niepełnosprawnych oraz odpowiedzialność za wykroczenia przeciwko przepisom omawianej ustawy.

\section{PODSUMOWANIE}

Podsumowując należy stwierdzić, że obowiązujące powszechnie regulacje normatywne zobowiązują władze publiczne do stworzenia warunków umożliwiających przełamywanie barier, jakie mają osoby niepełnosprawne w miejscach pracy.

Praca bowiem dla osób z dysfunkcjami umożliwia nie tylko pożądaną asymilację z osobami, wobec których nie stwierdzono stopnia niepełnosprawności, ale też pozwala określić skalę potencjalnych zagrożeń w tym środowisku, co w efekcie pozwala m.in. projektować rozwiązania ukierunkowane na zapewnienie bezpieczeństwa w tej sferze. I choć bez wsparcia finansowego większość przedsięwzięć w omawianym zakresie narażona jest na daleko idącą obstrukcję, tym niemniej tworzenie pożądanej atmosfery w miejscu pracy wymaga już nie tyle zaangażowania ekonomicznego, ile społecznego, czego należałoby oczekiwać nie tylko od pracowników, ale także od pracodawców wobec osób niepełnosprawnych.

\section{LITERATURA}

1. Barnes C., Mercer G., Niepetnosprawność, Warszawa 2008.

2. Garlicki L., Zubik M. (red.), Konstytucja Rzeczypospolitej Polskiej. Komentarz, t. II, wyd. II, Warszawa 2016.

\footnotetext{
${ }^{25}$ Art. 1 urzon.
} 
3. Gąciarz B. (red.), Niepetnosprawni studenci w społeczności akademickiej. Źródta sukcesów i porażek $w$ integracji społecznej $i$ aktywności zawodowej, Warszawa 2010.

4. Gould J.W., Kolb W.L. (red.), A Dictionary of the Social Sciences, London 1964.

5. Kaczmarek J., Łepkowski W., Zdrodowski B. (red.), Słownik terminów z zakresu bezpieczeństwa narodowego, Warszawa 2008.

6. Książkiewicz I., Lejzerowicz M., Osoba z niepetnosprawnościa a instytucje pomocowe, Wrocław 2012.

7. Nowak E., Nowak M., Zarys teorii bezpieczeństwa narodowego, Warszawa 2011.

8. Sadowska S., W stronę innego spojrzenia na szkotę jako miejsca terapii ucznia z niepetnosprawnościa intelektualna, „Człowiek - Niepełnosprawność - Społeczeństwo”, Kwartalnik Akademii Pedagogiki Specjalnej im. Marii Grzegorzewskiej nr 1, Warszawa 2005.

\section{PRAWODAWSTWO}

1. Konstytucja Rzeczypospolitej Polskiej z dnia 2 kwietnia 1997 r. (Dz.U. z 1997 r., nr 78, poz. 483 ze zm.).

2. Konwencja nr 159 Międzynarodowej Organizacji Pracy dotycząca rehabilitacji zawodowej i zatrudnienia osób niepełnosprawnych przyjęta w Genewie w dniu 20 czerwca 1983 r. (tekst jedn. Dz.U. z 2005 r., nr 43, poz. 412).

3. Ustawa z dnia 27 sierpnia 1997r. o rehabilitacji zawodowej i społecznej oraz zatrudnianiu osób niepełnosprawnych (tekst jedn. Dz.U. z 2018 r., poz. 511 ze zm.).

4. Ustawa z dnia 17 grudnia 1998 r. o emeryturach i rentach z Funduszu Ubezpieczeń Społecznych (tekst jedn. Dz.U. z 2018 r., poz. 1270 ze zm.).

5. Dyrektywa nr 2000/78/WE ustanawiająca ogólne warunki ramowe równego traktowania w zakresie zatrudnienia i pracy (Dz.U. UE. L. z 2003 r., nr 303, s. 16).

\section{LEGAL CONDITIONS FOR SAFETY OF DISABLED PEOPLE AT WORK}

Disability has accompanied a man from the beginning of his existence on Earth. The basic life issue of people with disabilities is finding a safe place in society that would allow them to use all available forms of professional activity and to arrange their own private life on a par with those without disabilities. In other words, the main life challenge for people with disfunctions should be to function in a manner that is closest to the accepted living standards of fully functional people, both in everyday life and at the place of their professional work. In order to achieve the intentional intention, the will, determination and appropriate professional predispositions are not enough. It is necessary that public institutions acting on the basis of binding legal regulations together with the social environment create favorable and safe conditions for such people in the workplace, but also the elements of medical rehabilitation most often associated with providing financial support are essential. The data from the World Disability Report show that over one billion people worldwide suffer from various forms of disability, of which between 110 and 190 million have serious disfunctions that prevent them from functioning normally in society, which indicates the scale of the presented issues. This article presents selected issues related to ensuring the safety of people with disabilities in the place where they are professionally involved in discussing the most 
important legal issues, including basic definitions, normative acts and Supreme Court rulings in this regard.

Keywords: safety, disability, work.

DOI: $10.7862 / \mathrm{rz} .2018 . \mathrm{mmr} .28$

Tekst złożono do redakcji: sierpień $2018 \mathrm{r}$.

Tekst przyjęto do druku: wrzesień 2018 r. 